\title{
Gas exchange at extreme altitude: results from the British 40th Anniversary Everest Expedition
}

\author{
A.J. Peacock*, P.L. Jones**
}

Gas exchange at high extreme altitude: results from the British 40th Anniversary Everest Expedition. A.J. Peacock, P.L. Jones. CERS Journals Ltd 1997.

ABSTRACT: Since Messner and Habeler climbed to the summit of Mount Everest $(8,848 \mathrm{~m})$ without oxygen in 1978 , there has been controversy between scientists trying to explain this feat. Field studies have suggested better respiratory performance than that found during a simulated climb in a hypobaric chamber, but the lack of data at extreme altitude has hampered the debate.

We measured arterial oxygen saturation $\left(\mathrm{Sa}_{\mathrm{a}}, \mathrm{O}_{2}\right)$ and alveolar partial pressure of oxygen $\left(\mathrm{PA}_{\mathrm{A}} \mathrm{O}_{2}\right)$ in nine subjects as they climbed from 3,500 to $8,000 \mathrm{~m}$. Four of the climbers reached $8,000 \mathrm{~m}$ and one reached the summit. We also tested the effects of breathing supplementary oxygen on $\mathrm{Sa}_{2}, \mathrm{O}_{2}$ at 6,550 and $8,000 \mathrm{~m}$.

At all altitudes tested, we found that both $\mathrm{P}_{\mathrm{A}, \mathrm{O}_{2}}$ and $\mathrm{Sa}_{\mathrm{a}} \mathrm{O}_{2}$ were higher than expected from low pressure chamber studies. We also found that standard rates of supplementary oxygen $\left(2 \mathrm{~L} \cdot \mathrm{min}^{-1}\right)$ were insufficient to restore $S_{\mathrm{a}, O_{2}}$ above $90 \%$ at $8,000 \mathrm{~m}$.

The respiratory performance of climbers at extreme altitude is better than expected from sea-level chamber studies, which may, in part, explain why humans can reach the summit $(8,848 \mathrm{~m})$ without added oxygen. The better performance is likely to be due to more appropriate acclimatization.

Eur Respir J 1997; 10: 1439-1444.
*Dept of Respiratory Medicine, Western Infirmary, Glasgow, UK. **Dept of Anaesthetics, University Hospital of Wales, Cardiff, UK.

Correspondence: A.J. Peacock Dept of Respiratory Medicine Level 4

Western Infirmary Glasgow G11 6NT UK

Keywords: Acclimatization altitude

alveolar partial pressure of oxygen arterial oxygen saturation hypoxia

Received: October 241996 Accepted after revision February 241997

AJP was supported by the Wellington Foundation and the study leave committee of the Western Infirmary.
In 1978, Peter Habeler and Rheinhold Messner made the first ascent of Everest $(8,848 \mathrm{~m})$ without supplementary oxygen $[1,2]$, despite predictions from respiratory physiologists that the maximum oxygen uptake ( $\mathrm{ca} 960$ $\mathrm{mL} \cdot \mathrm{min}^{-1}$ ) would only support basal metabolism and that it was "unlikely that the mountain could be climbed without oxygen equipment without severe risk" [3]. In an attempt to explain how humans cannot only survive but also climb without supplementary oxygen at extreme altitude, two important studies were carried out: one on Everest itself and the other simulating a climb of Everest in a hypobaric chamber. The American Medical Research Expedition to Everest (AMREE) (1981) measured alveolar partial pressure of oxygen $\left(\mathrm{PA}_{\mathrm{A}} \mathrm{O}_{2}\right)$ in gas samples from four subjects on the South $\mathrm{Col}(8,000 \mathrm{~m})$, one subject at $8,400 \mathrm{~m}$ and one subject on the summit $(8,848 \mathrm{~m})$. However, these values were not compared with measures of arterial oxygenation, such as arterial partial pressure of oxygen $\left(\mathrm{Pa}_{\mathrm{a}} \mathrm{O}_{2}\right)$ or arterial oxygen saturation $\left(\mathrm{Sa}_{\mathrm{a}} \mathrm{O}_{2}\right)$ at the same altitudes [4], although oxygen saturation was calculated from the measured $P \mathrm{~A}, \mathrm{O}_{2}$ [5].

In 1991, Operation Everest II simulated an ascent to extreme altitude by progressively decompressing nine healthy subjects over a period of 40 days in an air-filled chamber to a pressure equivalent to that at the summit of Everest [6,7]. The participants in Operation Everest II were comparable to those of AMREE: all were males aged 21-31 yrs, physically fit and participated in endurance sports; two had climed over $6000 \mathrm{~m}$. Measurements of $\mathrm{PA}, \mathrm{O}_{2}, \mathrm{Sa}_{2} \mathrm{O}_{2}$ and $\mathrm{Pa}_{\mathrm{a}} \mathrm{O}_{2}$ were made at many different "altitudes", up to and including "the summit". Since the results from these two sets of experiments were published, there has been considerable controversy because of the divergence in results between the alveolar gas samples $\left(P \mathrm{~A}, \mathrm{O}_{2}\right)$ obtained in the field by the AMREE and the alveolar gas samples obtained in the chamber by Operation Everest II. It appeared that the values obtained for $P A, \mathrm{O}_{2}$ on the mountain were significantly higher than those obtained in the chamber for the same altitude, and members of the American expedition claimed that the higher than expected values contributed significantly to the success of Habeler and Messner.

In an attempt to resolve the differences between these two studies and also to increase our understanding of gas exchange at extreme altitude, we measured $\mathrm{Sa}_{\mathrm{a}} \mathrm{O}_{2}$ and $\mathrm{PA}, \mathrm{O}_{2}$ simultaneously in a group of climbers at various altitudes between 3,500 and 8,000 $\mathrm{m}$ on the South Col of Everest. We believe that this is the highest point on Earth at which there has been a comparison of alveolar and arterial oxygenation in humans. These studies were performed as part of the physiological studies carried out during the British 40th Anniversary Everest Expedition in 1993.

\section{Methods}

\section{Subjects}

The subjects were nine healthy nonsmoking climbers (aged 32-53 yrs; 8 males and 1 female), all of whom 
were planning an attempt on the summit of the mountain. All of the climbers had previously climbed to an altitude of 4,600 $\mathrm{m}$ and four had climbed to over 8,000 $\mathrm{m}$, without suffering from altitude sickness. On this occasion, four of the nine climbers reached the South Col $(8,000 \mathrm{~m})$ and one reached the summit at $8,848 \mathrm{~m}$. Measurements of gas exchange were made between 3,500 and $8,000 \mathrm{~m}$. One subject (AJP) took acetazolamide throughout the climb but none of the others used either this or other relevant therapy. The protocol was approved by the West Ethics Committee and subjects gave informed consent.

\section{Measurements}

Arterial oxygen saturation. $\mathrm{Sa}_{2} \mathrm{O}_{2}$ was measured using a battery-powered, recording pulse oximeter (PneuPac Hand-Held Pulse Oximeter Version II; PneuPac Ltd, Luton, Beds, UK; manufactured as the BCI 3301 by BCI International, Waukesha, WI, USA), equipped with a finger probe. For each measurement, the subject maintained a sitting posture and was resting, having undertaken no exercise for the previous $5 \mathrm{~min}$. The subjects were seated inside a tent, the glove was removed and a finger probe applied, and then a large woollen glove was pulled back over the finger probe and hand to maintain hand warmth and a good pulse signal. Measurements were recorded when the observed saturation signal was stable. At higher altitudes, the saturation never fully stabilized because of Cheyne-Stokes breathing (see Discussion), making it necessary to record the average value of the saturation range displayed. The periodicity of swings of the displayed saturation was irregular, tending to cycle every 15-30 s, and increasing in amplitude with increasing altitude. Some subjects appeared to be more affected than others, though the response was also variable within individual subjects. The technique adopted was for the observer to note the maximum and minimum repeated readings during the swings of saturation over a period of two min, to record both, and then to calculate the average of the two readings. The value for $\mathrm{Sa}, \mathrm{O}_{2}$ was recorded immediately before or after determination of $\mathrm{PA}, \mathrm{O}_{2}$.

Because $\mathrm{Sa}_{\mathrm{a}} \mathrm{O}_{2}$ tend to be unreliable at very low levels, checks were made with this oximeter on a patient with a cardiac shunt. This patient was known to have a stable $\mathrm{Sa}_{\mathrm{a}} \mathrm{O}_{2}$ of $70 \%$, and the PneuPac recorded saturations between 69 and $71 \%$; values consistently identical to those provided simultaneously by a Nelcor oximeter, of similar design to the Pneupac, with its probe applied to an adjacent finger. Previous studies have shown that this type of oximeter is accurate against tonometry down to $\mathrm{Sa}_{\mathrm{a}} \mathrm{O}_{2}$ levels of $70 \%$ [8]. In this in vitro study, the standard error of oximeter estimates of $\mathrm{Sa}_{2} \mathrm{O}_{2}$ was $3.6 \%$, with a tendency to be higher at the lower ranges of saturation.

Alveolar partial pressure of oxygen. Measurements of gaseous oxygen tension were made using a temperature-compensated oxygen fuel cell sensor (Teledyne Electronic Devices Oxygen Sensor Class R17; Viamed, Keighley, West Yorks, UK). This device delivers a voltage that is directly proportional to the partial pressure of ambient oxygen $\left(\mathrm{PO}_{2}\right)$ and requires no external power source. Its output was measured in millivolts, using a portable battery-operated digital voltmeter. Its linearity of response at $21^{\circ} \mathrm{C}$ was checked against a series of precision gas mixtures, generated by Wustorf pumps in the range $15-160 \mathrm{mmHg}$, and was found to be linear $\left(\mathrm{PO}_{2}\right.$ $\left.(\mathrm{mmHg})=15.796(\mathrm{mV})-0.506 ; \mathrm{R}^{\wedge} 2=1.000\right)$. The time constant of its response to step changes in oxygen tension was demonstrated to be approximately $0.9 \mathrm{~s}$, thereby achieving a stable final output in less than $6 \mathrm{~s}$. The response to carbon dioxide in the gas mixture was tested using a Brüel \& Kjær multigas analyser and found to be insignificant. The sensor was placed in deep freeze and found to be little affected by stable temperatures down to $-22^{\circ} \mathrm{C}$. This remarkable stability is attributed to an internal thermal compensation circuit. When the chilled sensor was exposed initially to a stream of warm air $\left(37^{\circ} \mathrm{C}\right)$, some drift in response occurred, presumably because this caused a temperature difference between the oxygen sensor and the temperature compensation sensor. The response of the device was, at worst, reduced to approximately $95 \%$ of the true reading. This error was corrected by recording the response to ambient air immediately before and after every alveolar gas measurement. The sensor was mounted in a flexible sampling tube, which, when bent downwards, tended to trap exhaled warm air, thus allowing a sufficient length of time for contact between the fuel cell and the end-tidal expired gas.

For each subject measurement, the voltage output of the cell was first recorded while it was exposed to ambient air, and this was immediately followed by exposure to a sample of exhaled air. The subject was invited to grasp the plastic tube to his/her lips (fig. 1), inhale, then

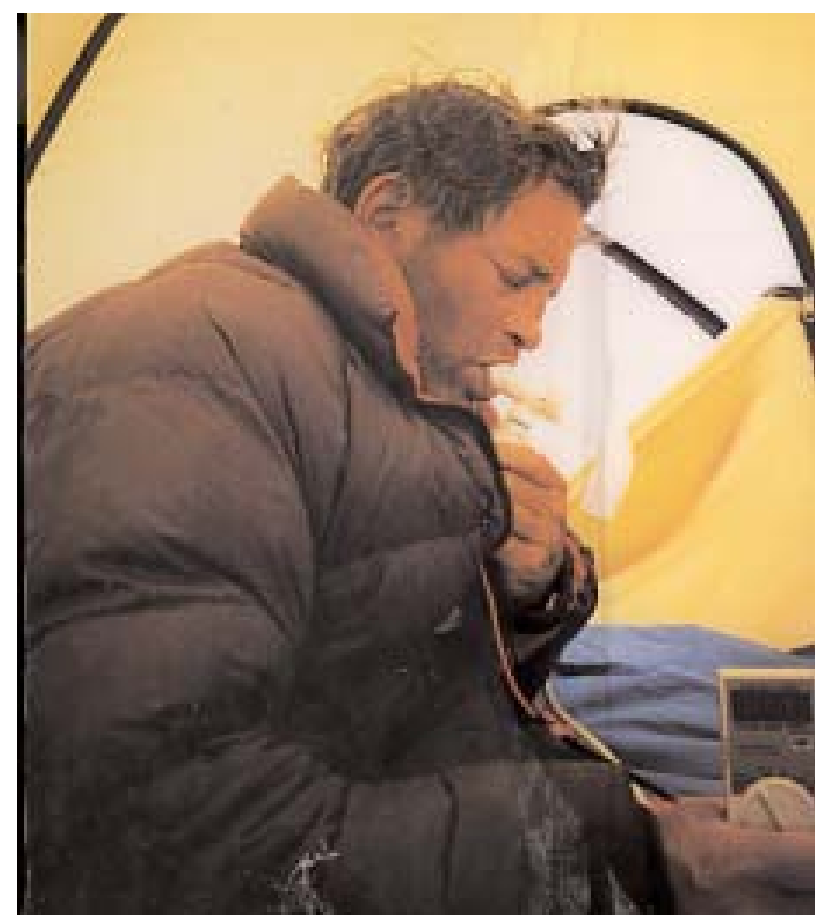

Fig. 1. - Measurement of alveolar partial pressure of oxygen on the South Col of Everest $(8,000 \mathrm{~m})$. The subject is exhaling into a tube connected to an oxygen fuel cell, which delivers a voltage proportional to the partial pressure of oxygen. Its output was measured in millivolts using a portable battery-operated digital voltimeter. 
perform a maximal exhalation, retaining the device against the closed lips for a period of at least $6 \mathrm{~s}$ in order to permit readings on the voltmeter to settle. Subjects were studied in a sitting position at rest, inside a tent where the temperature conditions were stable. It was confirmed that they had been resting for at least 5 min before measurements were made.

Spirometry. Forced expiratory volume in one second (FEV1) and forced vital capacity (FVC) were measured using a lightweight hand-held spirometer employing a Fleisch pneumotachograph (Vitalograph Ltd, Buckingham, UK). This instrument has been compared with a Vitalograph bellows spirometer and gives reproducible and accurate results at sea level [9]. The subjects were asked to perform three maximal expiratory manoeuvres, and the best FEV1 and its associated FVC were recorded.

Plan of Study. All subjects had pulmonary function testing (spirometry, lung volume estimation, and calculation of carbon monoxide transfer) performed in January 1993, approximately 3 months before leaving the UK for the expedition. At the same time, they also performed a progressive exercise test (oxygen consumption, carbon dioxide production, cardiac frequency $\left(f_{c}\right)$ and $\mathrm{Sa}_{\mathrm{a}} \mathrm{O}_{2}$ ). They also received a full medical examination and echocardiogram. In all cases, these tests were entirely normal for healthy athletes. All subjects flew to Katmandu, at an altitude of approximately 1,400 m, where they spent 3 days before travelling by bus to Jiri $(1,500 \mathrm{~m})$. At this point, they started their trek. The ascent profile is presented graphically in figure 2; Jiri is recorded as Day 2. Measurements of gas exchange and spirometry were made on the Lamjura Pass at 3,530 m, and subsequently at Chuckhung $(4,753 \mathrm{~m})$, Gorak Shep (5,288 m), Everest Base Camp (5,500 m), Camp 1 (6,248 $\mathrm{m})$, Camp $2(6,550 \mathrm{~m})$, Camp $3(7,467 \mathrm{~m})$ and Camp 4 on South Col $(8,000 \mathrm{~m})$. Altitudes were determined by altimeter, except where already known (Lamjura, Gorak Shep, Base Camp and the South Col). Measurements were made twice at Everest Base Camp, in order to

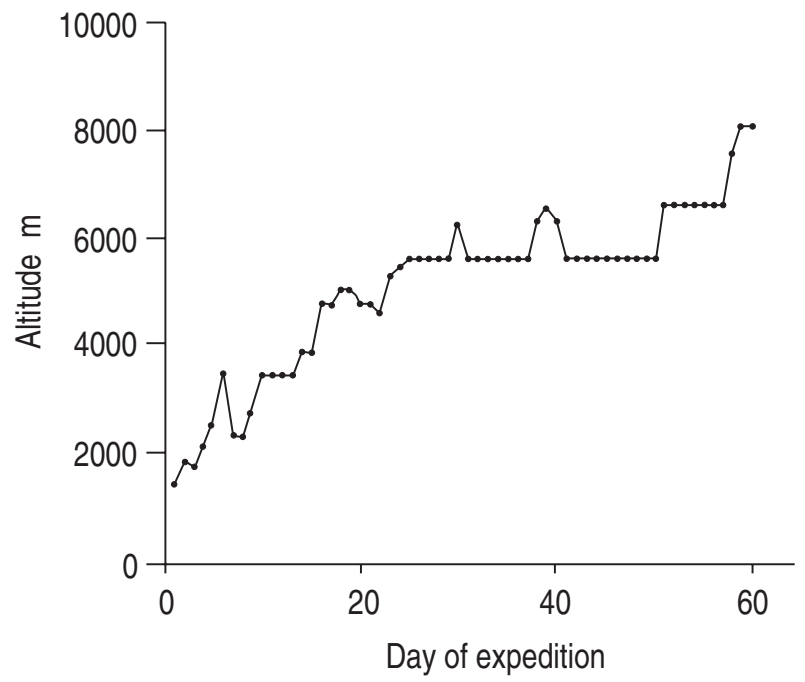

Fig. 2. - The ascent profile. The altitudes attained during the course of the British 40th Anniversary Everest Expedition from March 15 to May 10, 1993. determine the effect of acclimatization on gas exchange over the 3 week period between Day 29 and Day 50. $\mathrm{Sa}_{\mathrm{a}} \mathrm{O}_{2}$ was measured at all altitudes, but alveolar (endtidal) oxygen measurements were performed only at $3,530,5,288,5,550,6,550,7,467$ and $8,000 \mathrm{~m}$. In addition to $\mathrm{Sa}, \mathrm{O}_{2}$ while breathing ambient air, measurements were also made while breathing 1,2 or $3 \mathrm{~L} \cdot \mathrm{min}^{-1}$ of oxygen from an oxygen cylinder via a close-fitting oronasal mask. These additional measurements were made at Camp $2(6,550 \mathrm{~m})$ and Camp $4(8,000 \mathrm{~m})$.

\section{Statistical analysis}

Comparisons between these results and those of Operation Everest II were made using two-way analysis of variance (ANOVA). A p-value less than 0.05 was considered significant.

\section{Results}

None of the climbers developed severe altitude sickness or high altitude pulmonary oedema and there were no changes in spirometry.

\section{Arterial oxygen saturation}

Measurements of $\mathrm{Sa}_{\mathrm{a}} \mathrm{O}_{2}$ were performed successfully between 3,530 $\mathrm{m}$ (Lamjura) and 8,000 $\mathrm{m}$ (South Col of Everest). Not all subjects reached the South Col, and the numbers of subjects at each altitude declined from 10 at 3,530 m to four on the South Col (table 1).

Group mean data are presented in figure 3. For comparison, data from Operation Everest II are presented on the same graph [6]. It is clear that climbers in the field exposed to the same ambient pressure were better able to maintain $\mathrm{Sa}_{\mathrm{a}} \mathrm{O}_{2}$ than those in the hypobaric chamber $(p<0.05)$. Nevertheless, climbers on the mountain did desaturate to a mean resting value of only $70 \%$ on the South Col. Our results do not show a uniform linear relationship between altitude at which measurement

Table 1. - Location, altitude and day of measurement for the group of climbers $(n=10$ at lowest altitudes, and $\mathrm{n}=4$ at the highest altitudes) compared with $\mathrm{Pa}, \mathrm{O}_{2}$ and $\mathrm{Sa}, \mathrm{O}_{2}$

\begin{tabular}{lcccccc}
\hline Location & $\begin{array}{c}\text { Altitude } \\
\mathrm{m}\end{array}$ & $\begin{array}{c}\mathrm{Ss} \\
\mathrm{n}\end{array}$ & \begin{tabular}{c}
$\mathrm{S}_{\mathrm{a}, \mathrm{O}_{2}}$ \\
\cline { 5 - 7 }
\end{tabular} & \multicolumn{2}{c}{$P \mathrm{AA}, \mathrm{O}_{2}$} & Study \\
\hline Lamjura Pass & 3530 & 9 & $92 \pm 1$ & $8.5 \pm 0.2$ & $64 \pm 1.6$ & 6 \\
Namche Bazaar & 3440 & 10 & $91 \pm 1$ & $9.1 \pm 0.2$ & $68 \pm 1.6$ & 12 \\
Tengboche & 3870 & 10 & $93 \pm 1$ & $8.7 \pm 0.3$ & $65 \pm 2.2$ & 15 \\
Chuckhung & 4753 & 6 & $87 \pm 1$ & & & 17 \\
Gorak Shep & 5288 & 6 & $84 \pm 2$ & $7.6 \pm 0.3$ & $57 \pm 2.3$ & 23 \\
Base Camp & 5550 & 7 & $85 \pm 1$ & & & 29 \\
& & 7 & $89 \pm 1$ & $7.2 \pm 0.2$ & $54 \pm 1.4$ & 50 \\
Camp 1 & 6248 & 4 & $74 \pm 2$ & & & 30 \\
Camp 2 & 6550 & 5 & $79 \pm 1$ & $5.9 \pm 0.1$ & $44 \pm 1.1$ & 52 \\
Camp 3 & 7467 & 4 & $74 \pm 2$ & $5.1 \pm 0.1$ & $38 \pm 0.6$ & 58 \\
Camp 4 & 8000 & 4 & $70 \pm 1$ & $5.1 \pm 0.2$ & $38 \pm 1.2$ & 60 \\
\hline
\end{tabular}

Values of $\mathrm{Sa}_{\mathrm{a}} \mathrm{O}_{2}$ and $P \mathrm{~A}, \mathrm{O}_{2}$ are presented as mean \pm SEM. $\mathrm{Sa}_{\mathrm{a}} \mathrm{O}_{2}$ : arterial oxygen saturation; $P \mathrm{AA}_{2} \mathrm{O}_{2}$ : alveolar (end-expiratory) partial pressure of oxygen; Ss: Subjects. 


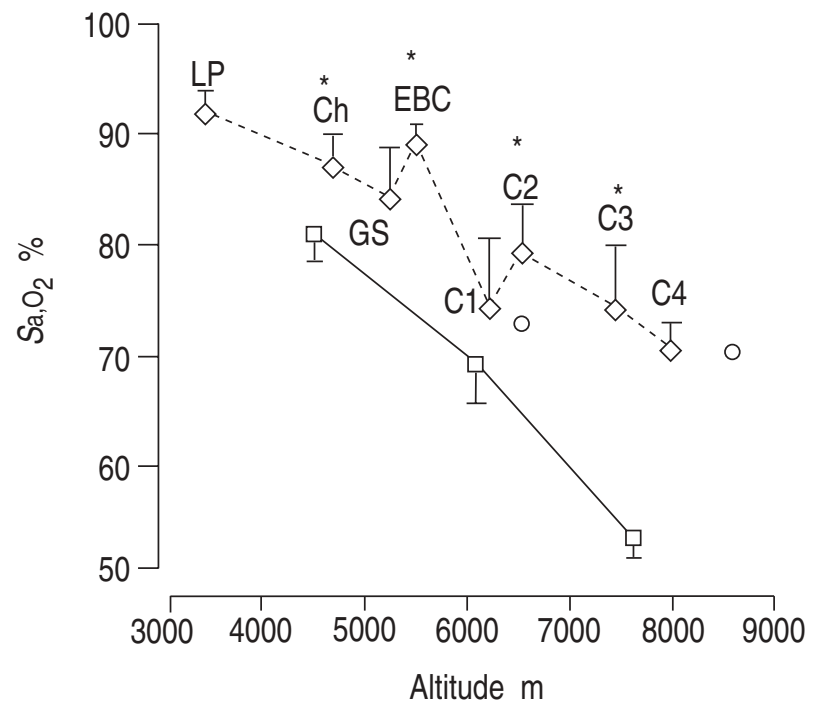

Fig. 3. - Arterial oxygen saturation $\left(\mathrm{S}_{\mathrm{a}, \mathrm{O}_{2}}\right)$ measured by pulse oximetry versus altitude in a group of climbers ascending from 3,500 to $8,000 \mathrm{~m}$. For comparison, the results obtained from the climbers are compared with the results obtained from a previous study, Operation Everest II, when nine subjects were decompressed in a hypobaric chamber to the "summit" of Everest over a period of 40 days [6]. Data are presented as mean \pm SEM. The values for $\mathrm{Sa}_{\mathrm{a}} \mathrm{O}_{2}$ in the field were higher than in the chamber. $\mathrm{Sa}_{\mathrm{a}} \mathrm{O}_{2}$ was measured twice at $\mathrm{EBC}$, on Days 29 and 50. Measurements at C1 were made on Day 30, early in the process of acclimatization. LP: Lamjura Pass; Ch: Chuckhung; GS: Gorak Shep; EBC: Everest Base Camp; C1: Camp 1; C2: Camp 2; C3: Camp 3; C4: Camp 4. $\square-\square$ : Operation Everest II; --British Everest Expedition; $\bigcirc$ : American Medical Expedition to Everest. *: $\mathrm{p}<0.05$, compared to Operation Everest II.

was made and $\mathrm{Sa}_{\mathrm{a}} \mathrm{O}_{2}$. This appears to depend on the time of acclimatization. For example, measurements were made twice at Everest Base Camp (5,550 m), on Day 29 (mean \pm SEM $\left.\mathrm{Sa}, \mathrm{O}_{2} 85 \pm 1 \%\right)$ and Day $50\left(\mathrm{Sa}_{\mathrm{a}} \mathrm{O}_{2} 89 \pm 1 \%\right)$. Mean $( \pm \mathrm{SEM})$ $\mathrm{Sa}, \mathrm{O}_{2}$ measured at Camp $1(6,248 \mathrm{~m})$ on Day 30 was only $74 \pm 2 \%$, whereas the values obtained at Camp $2(6,550$ $\mathrm{m}), 22$ days later, were actually higher than those obtained at the lower altitude of Camp 1 earlier in the period of acclimatization.

$\mathrm{Sa}_{\mathrm{a}, \mathrm{O}_{2}}$ measurements were also made at Camp 2 (6,550 $\mathrm{m})$ and the South $\mathrm{Col}(8,000 \mathrm{~m})$ while the resting subjects breathed oxygen using the equipment used for climbing, i.e. a tight-fitting oronasal mask. Results are presented in table 2 . They show that breathing oxygen at 2 $\mathrm{L} \cdot \mathrm{min}^{-1}$, at $6,550 \mathrm{~m}$ restored the $\mathrm{Sa}_{\mathrm{a}, \mathrm{O}_{2}}$ to almost the sealevel value, but breathing oxygen at $2 \mathrm{~L} \cdot \mathrm{min}^{-1}$, on the South Col achieved an $\mathrm{Sa}_{\mathrm{a}} \mathrm{O}_{2}$ of only $80 \%$. The flow rate allowed for climbing at a steady pace was $2 \mathrm{~L} \cdot \mathrm{min}^{-1}$. A flow rate of $3 \mathrm{~L} \cdot \mathrm{min}^{-1}$ was allowed only for exceptionally difficult climbing pitches, involving an increased degree of muscular work.

\section{Alveolar (end-expiratory) partial pressure of oxygen.}

Measurements of $\mathrm{PA}, \mathrm{O}_{2}$ were made at altitudes between $3,530 \mathrm{~m}$ (Lamjura Pass) and 8,000 $\mathrm{m}$ (South Col of Everest), but were not made at Base Camp on Day 29 or at Camp 1 on Day 30 (see above). The numbers of subjects examined at each altitude, the altitude, and the day of study are shown in table 1. Mean data are presented in figure 4. Once again, Operation Everest II data [5] are presented alongside, as well as available data from
Table 2. - The effect of supplementary oxygen on $\mathrm{Sa}, \mathrm{O}_{2}$ and $f_{c}$ at extreme altitude

\begin{tabular}{|c|c|c|c|c|}
\hline $\begin{array}{l}\text { Oxygen } \\
\text { supply }\end{array}$ & $\mathrm{n}$ & $\begin{array}{c}{\mathrm{Sa}, \mathrm{O}_{2}}_{\%} \\
\%\end{array}$ & $\begin{array}{c}f \mathrm{c} \\
\text { beats } \cdot \min ^{-1}\end{array}$ & $\begin{array}{c}\text { Study } \\
\text { day }\end{array}$ \\
\hline \multicolumn{5}{|c|}{ Camp $2(6,550 \mathrm{~m})$} \\
\hline Air & 5 & $75 \pm 2$ & $77 \pm 9.5$ & 52 \\
\hline $\mathrm{O}_{2} 1 \mathrm{~L} \cdot \mathrm{min}^{-1}$ & 5 & $82 \pm 2$ & $82 \pm 9.5$ & 52 \\
\hline $\mathrm{O}_{2} 2 \mathrm{~L} \cdot \mathrm{min}^{-1}$ & 5 & $91 \pm 1$ & $80 \pm 7.1$ & 52 \\
\hline $\mathrm{O}_{2} 3 \mathrm{~L} \cdot \mathrm{min}^{-1}$ & 5 & $97 \pm 0.2$ & $77 \pm 9.5$ & 52 \\
\hline \multicolumn{5}{|c|}{ Camp $4(8,000 \mathrm{~m})$} \\
\hline Air & 4 & $70 \pm 2$ & $100 \pm 10$ & 60 \\
\hline $\mathrm{O}_{2} 1 \mathrm{~L} \cdot \mathrm{min}^{-1}$ & 4 & $76 \pm 4$ & $90 \pm 9$ & 60 \\
\hline $\mathrm{O}_{2}^{2} 2 \mathrm{~L} \cdot \mathrm{min}^{-1}$ & 4 & $80 \pm 4$ & $89 \pm 13$ & 60 \\
\hline
\end{tabular}

Four subjects breathed oxygen from a tight-fitting oronasal mask, whilst sitting at rest. The oxygen flow rate varied from 1-4 L. $\mathrm{min}^{-1}$. Measurements were made at Camp $2(6,550 \mathrm{~m})$ and the South $\mathrm{Col}(8,000 \mathrm{~m})$. Values of $\mathrm{Sa}_{\mathrm{a}, \mathrm{O}_{2}}$ and $f_{\mathrm{c}}$ are presented as mean \pm SEM. The regulation oxygen supply $\left(2 \mathrm{~L} \cdot \mathrm{min}^{-1}\right)$ was sufficient at $6,550 \mathrm{~m}$ but did not restore oxygen saturation at $8,000 \mathrm{~m}$. $S_{\mathrm{a}, \mathrm{O}_{2}}$ : arterial oxygen saturation; $f \mathrm{c}$ : cardiac frequency.

the AMREE [4]. Mean ( \pm SEM) values for $\mathrm{PA}, \mathrm{O}_{2}$ declined from $8.5 \pm 0.2 \mathrm{kPa}(64 \pm 1.6 \mathrm{mmHg})$ on Lamjura Pass to $5.1 \pm 0.08 \mathrm{kPa}(38 \pm 0.6 \mathrm{mmHg})$ at $7,467 \mathrm{~m}$ at Camp 3, but there was no further decline at $8,000 \mathrm{~m}\left(\mathrm{PA}, \mathrm{O}_{2} 5.1 \pm 0.2\right.$ $\mathrm{kPa}(38 \pm 1.2 \mathrm{mmHg}))$. This flattening out of the decline in $P$ A, $\mathrm{O}_{2}$ agrees both with the values from AMREE and also the values from Operation Everest II. However, although the pattern of change of $P A, O_{2}$ in our subjects followed the pattern of change in the subjects in Operation Everest II, the values at all altitudes were higher in those actually on the mountain $(\mathrm{p}<0.05)$, indicating, as with the $\mathrm{Sa}_{\mathrm{a}} \mathrm{O}_{2}$, that the $P \mathrm{~A}, \mathrm{O}_{2}$ was maintained better amongst the climbers than it was amongst the subjects in the hypobaric chamber.

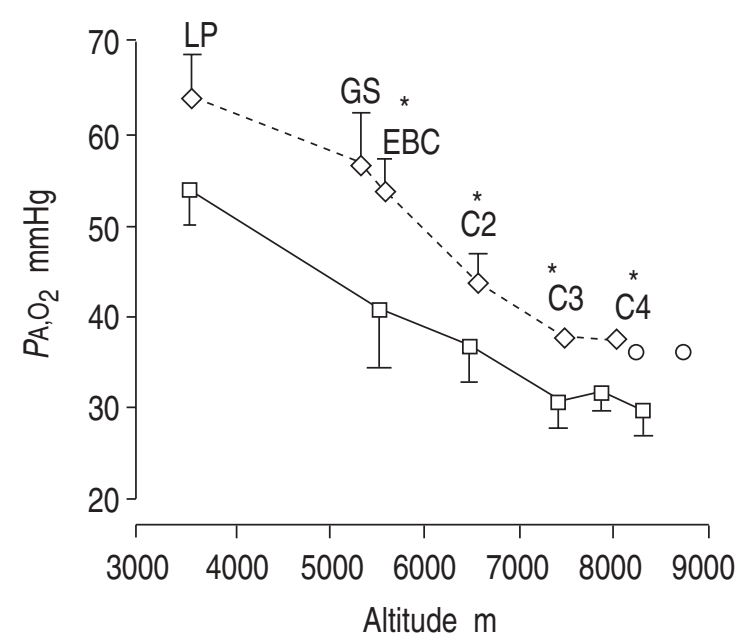

Fig. 4. - Partial pressure of oxygen in alveolar (end-expiratory) gas $\left({\mathrm{PA}, \mathrm{O}_{2}}_{2}\right)$, measured using an oxygen fuel cell, versus altitude in a group of climbers ascending from 3,500 to $8000 \mathrm{~m}$. For comparison, the results obtained from the climbers are compared with the results obtained from a previous study, Operation Everest II, when nine subjects were decompressed in a hypobaric chamber to the "summit" of Everest over a period of 40 days [5], and another field study, the American Medical Research Expedition to Everest (AMREE) where five measurements of $P \mathrm{~A}_{1} \mathrm{O}_{2}$ were made at $8,050 \mathrm{~m}$, one at $8,400 \mathrm{~m}$ and one at $8,848 \mathrm{~m}$ [1]. Data are presented as mean \pm SEM. $\square \square-$ : Operation Everest II;-- $\diamond$---: British Everest Expedition; $\bigcirc$ : AMREE. $*: \mathrm{p}<0.05$, compared to Operation Everest II. For definitions see legend to figure $3.1 \mathrm{mmHg}=0.133 \mathrm{kPa}$. 


\section{Discussion}

We studied a group of experienced climbers, with no previous history of altitude-related illness, as they ascended from Lamjura pass at 3,350 $\mathrm{m}$ in the Himalaya to the South Col of Mount Everest at $8000 \mathrm{~m}$. The slow pace of ascent meant that they were well-acclimatized. None of the subjects developed symptoms of high altitude pulmonary oedema at these altitudes, and we found no change in spirometry during the ascent from Lamjura to Camp 2 (3,350 $\mathrm{m}$ to $6,550 \mathrm{~m}$ ), although there is doubt about the accuracy of the spirometer at high altitude. One of the subjects (AJP) developed symptoms of excessive breathlessness at Camp $4(8,000 \mathrm{~m})$ and needed evacuation. Interestingly, he was the only climber taking acetazolamide. Acetazolamide is known to potentiate the hypoxic ventilatory response [10]. He inadvertently stopped taking the drug before climbing to Camp 4 from Camp $2(6,550 \mathrm{~m})$. It is possible that his deterioration was related to this sudden cessation of the carbonic anhydrase inhibitor. However, measurements of gas exchange in this individual were no different from the results obtained in the other climbers, who were not taking acetazolamide, suggesting that, under the conditions of extreme hypoxia prevalent at these altitudes, the drug was not affecting respiratory drive, which was already maximally stimulated.

The main findings of the present study were as follows. In well-acclimatized individuals, who had no previous history of high altitude pulmonary oedema, there was a linear fall in $\mathrm{PA}, \mathrm{O}_{2}$ from $8.5 \mathrm{kPa}(64 \mathrm{mmHg})$ at $3,530 \mathrm{~m}$ to $5.1 \mathrm{kPa}(38 \mathrm{mmHg})$ at $7,467 \mathrm{~m}$, but no further fall in $P A, O_{2}$ at $8,000 \mathrm{~m}$, the highest altitude of measurement. This pattern of change in $\mathrm{PA}_{2} \mathrm{O}_{2}$ was accompanied by a linear fall in $\mathrm{Sa}_{2} \mathrm{O}_{2}$ from $92 \%$ at 3,530 $\mathrm{m}$ to $74 \%$ at $7,467 \mathrm{~m}$ and $70 \%$ at $8,000 \mathrm{~m}$. In the same individuals, when less acclimatized, there were notably lower saturations for the same altitudes, indicating the importance of acclimatization. Breathing oxygen from oxygen equipment increased measured resting saturations. At Camp $2(6,550 \mathrm{~m}), \mathrm{Sa}_{\mathrm{a}} \mathrm{O}_{2}$ was adequate using oxygen at a flow rate of $2 \mathrm{~L} \cdot \mathrm{min}^{-1}\left(\mathrm{Sa}_{2} \mathrm{O}_{2} 91 \%\right)$, and normal for sea level while breathing oxygen at a flow rate of $3 \mathrm{~L} \cdot \mathrm{min}^{-1}$. In contrast, on the South Col (altitude $8,000 \mathrm{~m}), \mathrm{Sa}_{\mathrm{a}} \mathrm{O}_{2}$ reached only $80 \%$ using oxygen at a flow rate of $2 \mathrm{~L} \cdot \mathrm{min}^{-1}$.

To our knowledge, no other high altitude study has compared alveolar and arterial oxygenation at altitudes as high as 8,000 $\mathrm{m}$ on a mountain. During AMREE, some measurements of $\mathrm{PA}, \mathrm{O}_{2}$ were made at 7,500 and 8,500 $\mathrm{m}$, but there were no simultaneous measurements of $\mathrm{Sa}_{\mathrm{a}} \mathrm{O}_{2}$. During Operation Everest II, all measurements were made in the stable temperature-controlled conditions of an hypobaric chamber. It is, therefore, interesting to compare the present results with those of Operation Everest II. We found that $\mathrm{PA}_{2} \mathrm{O}_{2}$ and $\mathrm{Sa}, \mathrm{O}_{2}$ followed the same pattern of decline with altitude on the mountain as Operation Everest II found in the chamber; there was a linear fall in values to $7,500 \mathrm{~m}$, and then the fall reached a plateau, such that there was no further fall at $8,000 \mathrm{~m}$. However, our results were consistently higher than those achieved in the chamber, so it is important to ask whether we suffered errors in measurement to account for these differences.
We used a fuel cell to measure $P \mathrm{~A}_{2} \mathrm{O}_{2}$. We believe the results to be accurate for the following reasons. Laboratory tests demonstrated that the response of the fuel cell was linear throughout the test (and clinical) range. Calibration was cross-checked using calculated atmospheric pressure and calculated ambient partial pressure of oxygen for the given altitude, since there was no means of checking the calibration of altimeters during the expedition. The in-built temperature compensation mechanism was found to be effective throughout the expedition experimental range, being only susceptible to sudden changes in temperature brought about by the succession of subjects exhaling through the device during each testing episode. The change in response was compensated by recording the response to ambient air between each successive alveolar air determination, and using these data to determine the value of the $P \mathrm{~A}, \mathrm{O}_{2}$.

Results were reproducible and agreed with those of a previous field study (AMREE)[4]. In particular, we also found that $P \mathrm{~A}, \mathrm{O}_{2}$ did not decline further from Camp 3 at $7,467 \mathrm{~m}$ to the South $\mathrm{Col}$ at $8,000 \mathrm{~m}$.

$\mathrm{Sa}_{2} \mathrm{O}_{2}$ values were measured using pulse oximetry. Known sources of error in pulse oximetry are: poor pulse signal with cold extremities; fluctuation of saturation at higher altitudes; and a tendency to underestimate $\mathrm{Sa}_{\mathrm{a}} \mathrm{O}_{2}$ under conditions of severe hypoxia.

We took great care to ensure that subjects' fingers were warm at the time of measurement. The fluctuation in $\mathrm{Sa}, \mathrm{O}_{2}$ at higher altitudes is an interesting phenomenon, presumably related to fluctuating ventilation (daytime Cheyne Stokes breathing), and was also seen in Operation Everest II, where fluctuations in $\mathrm{Sa}_{\mathrm{a}} \mathrm{O}_{2}$ of more than $6 \%$ were reported [7]. We chose to record the mean of the highest and lowest values measured but it is impossible to say whether this was the "true saturation". It is possible that we overestimated saturation at higher altitudes, because the oximeter used was known to overestimate $\mathrm{Sa}_{\mathrm{a}} \mathrm{O}_{2}$ at saturations of $\mathrm{ca} 70 \%$. However, since the lowest saturations that we were measuring were in the order of $70 \%$, it is unlikely that there was significant overestimation below $8,000 \mathrm{~m}$, and even then in vitro studies suggest that the error was unlikely to exceed $4 \%$ [8].

The most interesting feature of our results is that the $P \mathrm{~A}, \mathrm{O}_{2}$ and $\mathrm{Sa}, \mathrm{O}_{2}$ were greater by approximately $0.9 \mathrm{kPa}$ $(7 \mathrm{mmHg}$ ) and 7-20\%, respectively, than those for Operation Everest II. This implies either that our results were overestimated, or that there is an important difference between the ventilatory response to hypobaric hypoxia in a chamber when compared with that response on the mountain. We believe that it is unlikely that a fault in our measurements was responsible because: our results were so consistent; the differences in the results between studies were consistent; our values for $P \mathrm{~A}, \mathrm{O}_{2}$ were similar to those for another field study (AMREE); and our (measured) values of $\mathrm{Sa}_{\mathrm{a}} \mathrm{O}_{2}$ agreed with the calculated $\mathrm{Sa}_{\mathrm{a}, \mathrm{O}_{2}}$ from the same study (AMREE). If the differences between the study were real, then we need an explanation. The most likely explanation for the differences was the better acclimatization of our subjects. Our subjects did not reach the South Col $(8,000 \mathrm{~m})$ until Day 60, whereas Operation Everest II lasted for only 40 days right up to the "summit" at $8,848 \mathrm{~m}$. Furthermore, our subjects were exercising consistently at these altitudes, 
which may have improved their acclimatization. The role of acclimatization was demonstrated best by the differences between the saturation measurements performed earlier and those performed later in the expedition, i.e. allowing time for acclimatization. We found that mean saturation at Base Camp $(5,500 \mathrm{~m})$ was $85 \%$ on Day 29, but $4 \%$ higher on Day 50. Similarly, saturation at Camp $1(6,248 \mathrm{~m})$ was only $74 \%$ on Day 30 , but on Day 52, at Camp 2, (300 m higher than Camp 1) was $5 \%$ more. There is further support for this argument from the Operation Everest II study itself, where $P \mathrm{~A}_{2} \mathrm{O}_{2}$ at $8,060 \mathrm{~m}$ was $4.1 \mathrm{kPa}(31 \mathrm{mmHg})$ on Day 32 but $4.8 \mathrm{kPa}(36 \mathrm{mmHg})$ on Day 40 .

Part of the goal of our expedition was to assess oxygen requirements during climbs at extreme altitude. The standard rule for oxygen use is $2 \mathrm{~L} \cdot \mathrm{min}^{-1}$ above Camp $3(7,467 \mathrm{~m})$ and $2-3 \mathrm{~L} \cdot \mathrm{min}^{-1}$ above Camp $4(8,000 \mathrm{~m})$, while using simple face-masks. We found that a flow rate of $2 \mathrm{~L} \cdot \mathrm{min}^{-1}$ provided adequate oxygenation at rest at Camp 2, but was totally inadequate at Camp $4(8,000$ $\mathrm{m})$, where mean saturation was only $80 \%$. The range of saturations amongst the four subjects at this altitude was $77-86 \%$ using $2 \mathrm{~L} \cdot \mathrm{min}^{-1}$ oxygen. It is interesting that the individual with the best response to oxygen (her $\mathrm{Sa}_{\mathrm{a}} \mathrm{O}_{2}$ rose from $70 \%$ on air to $86 \%$ on oxygen) was the only one to reach the summit. In comparison, the two subjects with the worst response to added oxygen (their $\mathrm{Sa}_{\mathrm{a}} \mathrm{O}_{2}$ rose from 69 to only $77 \%$ on $2 \mathrm{~L} \cdot \mathrm{min}^{-1}$, with no further rise on $4 \mathrm{~L} \cdot \mathrm{min}^{-1}$ ) were forced to descend back to Camp 2 because of high altitude deterioration. Expedition instructions, issued to conserve oxygen, dictated that a flow rate of $2 \mathrm{~L} \cdot \mathrm{min}^{-1}$ be used for normal climbing, and $3 \mathrm{~L} \cdot \mathrm{min}^{-1}$ only for difficult pitches at extreme altitude. Clearly, exercising at these altitudes will cause further deoxygenation. Unfortunately, our data recorded during climbing above Camp 2 were lost. It is safe to speculate, however, that profound desaturation occurred, even when breathing additional oxygen.

It has been known since 1978 that humans can climb to the summit of Everest without supplementary oxygen.
Our study has provided further evidence that respiratory acclimatization is the key to the ability of humans to survive at extreme altitude.

Acknowledgements: The authors wish to thank the climbing members of the expedition: H. Taylor, R. Stephens, J. Barry, D. Walsh, S. Scott, B. Barker, P. Earl and M. Rhodes for their patience and enthusiasm.

\section{References}

1. Messner R. Everest: expedition to the ultimate. London, Kaye and Ward, 1979.

2. Habeler P. Everest: impossible victory. London, Arlington Books, 1979.

3. Pugh LGCE. Muscular exercise on Mount Everest. $J$ Physiol 1958; 141: 233-261.

4. West JB, Hackett PH, Maret K, et al. Pulmonary gas exchange on the summit of Mount Everest. J Appl Physiol: Respirat Environ Exercise Physiol 1983; 55(3): 678-687.

5. Winslow RM, Samaja M, West JB. Red cell function at extreme altitude on Mount Everest. J Appl Physiol: Respirat Environ Exercise Physiol 1984; 56(1): 109-116.

6. Malconian MK, Rock PB, Reeves JT, Cymerman A, Houston CS. Operation Everest II: gas tensions in expired air and arterial blood at extreme altitude. Aviat Space Environ Med 1993; 64: 37-42.

7. Anholm JD, Powles AC, Downey R, et al. Operation Everest II: arterial oxygen saturation and sleep at extreme simulated altitude. Am Rev Respir Dis 1992; 145: 817-826.

8. Reynolds KJ, Moyle JTB, Sykes MK, Hahn CEW. Response of 10 pulse oximeters to an in vitro test system. Br J Anaesth 1992; 68: 365-369.

9. Wiltshire N, Kendrick AH. Evaluation of a new electronic spirometer: the Vitalograph "Escort" Spirometer. Thorax 1994; 49: 175-178.

10. Burki NK, Khan SA, Hameed MA. The effects of acetazolamide on the ventilatory response to high altitude hypoxia. Chest 1992; 101: 736-741. 